\title{
ПСИХОЛОГИЧЕСКОЕ ЗДОРОВЬЕ В АСПЕКТЕ ЭКОЛОГИИ ЛИЧНОСТИ
}

\author{
Белоус Ольга Валерьевна \\ к.nсх.н., доцент, ФГБОУ ВО «Армавирский \\ государственный педагогический университет» \\ belous_a@inbox.ru
}

\section{PSYCHOLOGICAL HEALTH IN THE ASPECT OF PERSONALITY ECOLOGY \\ O. Belous}

Summary: The article deals with the substantive aspects of the psychological health of the individual in the aspect of the environmental approach. Determinants of subjective well-being showing the nature of psychological health of the individual are presented in a meaningful way. The functions of psychological health are considered, among which in modern conditions the most relevant is to maintain an active dynamic balance between personality and environment in situations requiring resource mobilization. In general, it has been proved necessary to experience well-being in order to preserve and strengthen the sanogenic potential of the individual.

Keywords: personality, psychological health, personality ecology, subjective well-being, self-regulation, self-actualization.
A ктуальным в последнее время в аспекте использования гуманистического и индивидуально-ориентированного подходов к развитию человека является заинтересованность ученых и практиков к изучению качества жизни, достижения субъективного благополучия личности. Для человека стремление к благополучию и положительному функционированию является одной из детерминант самоактуализации и становления. В связи с этим проблема получения и поддержки субъективного ощущения требует рассмотрения.

Забота о субъективном благополучии и психологическом здоровье предполагает внимание к внутреннему миру человека: его чувствам и переживаниям, увлечениям и интересам, способностям и знаниям, его отношения к себе и окружающим, природе, делу, проявлению психофизиологических и регулятивных возможностей и т.д. Именно поэтому развитая личность характеризуется наличием арсенала адекватных средств самопонимания, самопринятия и саморазвития в контексте взаимодействия с окружающими его людьми и реалиями.

Разработкой основных подходов к определению благополучия в целом занимались: N. Bradburn, P.T. Costa, E.L. Deci, Ed Diner, M. W. Fordyce, M. Jahoda, R.R. McCrae, R. M. Ryan, C. Ryff, P. Warr, A.S. Waterman, E. Бенко, A.B. Boронина, Т.В. Данильченко, Л.В. Куликов, П.П. Фесенко, Т.Д. Шевеленкова, А.С. Ширяева и др. [3, 5, 10, 11].
Проблема субъективного благополучия представлена в исследованиях М. Аргайл, Н.К. Бахаревой, Е.Е. Бочаровой, А.В. Ворониной, Ed. Diner с коллегами (Sandvik, Pavot, Fujita), Ю.Б. Дубовик, О.А. Елисеевой, М. Селигман, Р.М. Шамионова и др. [5, 9].

Самое общее рассмотрение феномена благополучия представлено в исследованиях Ed. Dinera. Согласно его мнению, субъективное благополучие отражает оценку человеком своей жизни и включает в себя счастье, положительные эмоции, удовлетворенность жизнью и относительное отсутствие негативных эмоций и настроений. Ed. Diner выделил качественно представленные уровни оценки жизни в аспекте благополучия: уровень общей удовлетворенности жизнью, уровень удовлетворенности отдельными сферами жизнедеятельности (браком, учебой, работой), уровень эмоциональной удовлетворенности (качество и частота испытываемых человеком эмоциональных состояний).

В проводимых в последние годы исследованиях рассматривается, что благополучие является относительно устойчивым интегральным многокомпонентным феноменом. Как сложный феномен характеризует состояние оптимального функционирования человека и детерминировано различными факторами, в том числе: системы личностных представлений о себе и мире, системе ценностей, характере наличия эмоциональных шаблонов, поведенческих установок и стереотипов, коммуникатив- 
ных умений и навыков, личностных качеств, жизненных целей, содержания интеллекта.

В рамках рассмотрения субъективного благополучия более значимыми для рассмотрения характера действия психологических факторов успешности выступают личностные характеристики человека: самопринятие, позитивные отношения с другими, автономность, компетентность, цели в жизни, личностный рост и т.п. [8].

Также рядоположенно с понятием «благополучие» в психолого-педагогической и философской литературе используется комплекс различных феноменов, в частности счастье, психическое здоровье, удовлетворенность жизнью, качество жизни, психологическое благополучие, субъективное благополучие и др.

На основании теоретического анализа существующих исследований субъективного благополучия актуальны 2 позиции: 1) проблема самосознания, рефлексивного «Я» в рамках исследований «от личности»; 2) проблема «внешнего» (по отношению к личности) содержания как условия усиления индекса благополучия в рамках исследований «к личности»[11].

М.В. Соколова в своих исследованиях предлагает три аспекта категориального определения субъективного благополучия на основе анализа данного феномена:

1. рассматривается по внешним критериям «нормативности» (в аспекте соответствия системе ценностей, принятой в конкретном обществе и культуpe);

2. рассматривается через призму понятия удовлетворенности жизнью и связывается со стандартами в отношении внутренних нормативов "хорошей жизни» личности;

3. рассматривается через призму обыденного, традиционного понимания счастья как превосходства положительных эмоций над отрицательными [9].

Итак, можно характеризовать субъективное благополучие личности как особое интегральное феноменальное социально-психологическое образование, включающее активное оценивание и отношение к своей жизнедеятельности, к себе, к своему поведению и проявлениям во всех сферах реализации. В данном феномене можно выделить традиционные компоненты психического явления (когнитивный, эмоциональный, конотативный (поведенческий)) и характеристики (субъективность, позитивность и глобальность измерения) (Ed. Diner).

При характеристике функций значимости и действия субъективного благополучия также много точек зрений на их выделение. Фактически рассматривают четыре до- статочно общие функции:

1. регулятивная функция или функция адаптации. Она заключается в регуляции внутреннего самоотношения, самочувствия, а также взаимоотношения с внешним миром. Определяет усиление адаптационных возможностей человека в восприятии себя и своей жизни. Соотносится со способностью саморегуляции человека.

2. функция управления познанием, когнитивными процессами - обеспечивает адаптацию и интеграцию личности в социуме. Соотносится с социализацией, развитием человека. Проявляется в понимании и использовании актуального уровня развития, имеющихся знаний и субъектного опыта в аспекте соотнесения необходимости использования и «актуальности».

3. функция развития - обеспечивает характер саморазвития, понимания возможностей использования окружающей действительности для удовлетворения высших потребностей и приведения всей системы личности в равновесие возможностей, потребностей и реального отреагирования.

При анализе теоретической литературы можно увидеть концептуальные различия разных подходов, которые были отражены в различных «авторских» моделях благополучия (А. Campbell, P. E. Converse, W.L. Rodgers, 1976; N. Bradburn, 1969; Ed Diner, 1984, 1995, 2002, 2009; Ed Diener, J.S. Larsen, S. Levine, R.A. Emmons, 1985; Ed Diener, E. Sandvik, W.G. Pavot, 1991; Ed Diener, J.S. Larsen, 1993; C. Ryff, 1986; C. D. Ryff, C. L. M. Keyes, 1995; Л. В. Kyликов; А. С. Ширяев (2008); Ю.М. Александров (2009); Т.В. Данильченко (2015) и др.) [12].

Рифф К. рассматривает психологическое благополучие как базовый субъективный конструкт, отражающий восприятие и оценку своего функционирования с точки зрения вершины потенциальных возможностей человека [13].

Рассматривая содержание и проявления субъективного благополучия, можно отметить его взаимосвязь и соответствие психологическому и социальному здоровью человека, актуализация идеалов, оптимизма, настроенности на завтрашний день. Можно сказать, что данный феномен является одной из детерминант полноценного существования личности, ее внутренней силы и оптимистичного настроя.

Данное утверждение реализуется в различных исследованиях содержания психологического здоровья человека, когда психологическое благополучие соотносят с психическим и психологическим здоровьями.

В частности, в разработанной концепции А.В. Ворониной уровни модели психологического благополучия 
соответствуют феноменам «психическое здоровье» и «психологическое здоровье». Данный вид благополучия реализовывает и показывает согласие человека с самим собой, его внутреннюю целостность и гармонию, является системным личностным качеством. Именно благополучие как целостность человек приобретает и организует самостоятельно в процессе собственной жизнедеятельности. [5]

В исследованиях Н.А. Батурина - психологическое благополучие личности соотносится саморегуляцией личности, выступая как результат саморегуляции психических состояний, восприятие жизни [1].

При взаимодействии с окружающим миром человек непрерывно сталкивается с ситуацией выбора различных способов реализации своей активности в зависимости от своих целей, индивидуальных особенностей и условий окружающей его действительности, особенностей взаимодействия с ним людей. В таком случае снятие неопределенности возможно лишь средствами регуляции, а в случае психической регуляции - средствами саморегуляции в том смысле, что человек сам исследует ситуацию, программирует свою активность и контролирует, и корректирует результаты (Конопкин О.А., 1980, Ломов Б.Ф., Сурков Е.Н., 1980, Степанский В.И., 1981). Формирование единой для множества разных деятельностей системы саморегуляции позволяет подготовить человека в будущем к перемене поведения в трансформирующихся ситуациях, адаптации к постоянно меняющимся условиям окружающей действительности [2].

Главной особенностью методов саморегуляции человека является направленность на формирование соответствующих адекватных внутренних средств, позволяющих человеку осуществить целенаправленную активность по изменению своего состояния и характера жизнедеятельности.

Из этого можно сделать вывод о важности регулятивных умений в содержании переживания благополучия в аспекте сохранения и укрепления саногенного потенциала личности. В своей жизнедеятельности человек вынужденно постоянно преодолевает трудности и барьеры, которые по-разному воздействуют на психику на характер субъективного опыта. Действительно, именно психологическая устойчивость личности позволяет сохранить душевное равновесие, ощущение удовлетворенности, настроенность на решение и преодоление конфликтов субъективных и социальных. Но в реальности потенциал устойчивости ограничен и определяется субъективным опытом восприятия ситуации, качеством отреагирования на стрессоры, желанием позитивной жизнедеятельности, состоянием физического и телесного благополучия и пр.
Итак, понятия здоровье и благополучие имеют точки соприкосновения и область пересечения содержания. В частности, благополучие и здоровье равнозначно предполагают реализацию физических и духовных потенций человека. Соответственно, процесс самореализации человека в целях достижения благополучия будет основан на достаточной психологической устойчивости и саморегуляции.

В рамках данных исследований можно представить основную функцию психологического здоровья в направленности поддержания активного баланса взаимодействия личности и окружающей средой в ситуациях, требующих мобилизации ресурсов, в стрессовых ситуациях и пр. При наличии психического и психологического здоровья человек может оптимально и эффективно функционировать в аспектах физиологии и психики в реальной жизнедеятельности [4].

Методологически и содержательно термин «психологическое здоровье» был определен И.В. Дубровиной. В данный феномен были включены психологические аспекты психического здоровья, как то, что соотносится с личностью в целом и находится во взаимосвязи со всеми проявлениям человеческого духа [7].

Психологическое здоровье по определению является необходимым условием полноценного функционирования и развития человека в процессе его жизнедеятельности. Данный вид здоровья является условием адекватного выполнения человеком своих возрастных, социальных и культурных ролей и обеспечивает человеку возможность непрерывного развития в течение всей его жизни.

Как на любое психическое явление, состояние психологического здоровья определяется комплексом факторов. Как социальный феномен, оно зависит от следующих моментов:

1. Принятие ответственности за свою жизнь и здоровье.

2. Самопознание как анализ самого себя. В рамках самопознания определяется содержание понимания человеком своих возможностей, ресурсов, механизмов протекания психологических защит, используемых личностью для сохранения собственного достоинства и самоуважения.

3. Самопонимание и принятие себя как личности. При действии данного фактора появляется возможность принимать самого себя как личность, уникальную и представленную в своем своеобразии, формируется умение разрешать внутренние противоречия, лежащие в основе внутриличностных конфликтов, непринятия и недовольства самим собой и окружающими.

4. Умение жить в настоящем моменте, понимая ре- 
альность и выстраивая ситуацию отреагирования на «здесь и сейчас».

5. Осмысленность индивидуального бытия, определяющая иерархию смыслов и ценностей, на основе которые личность входит в «проживание» жизни с осознанием ситуаций простраивания своего будущего в соответствии с окружающей действительностью.

6. Способность к пониманию, слышанию и слушанию, принятию других. Фактически это проявляется как эмпатическое понимание, основанное на сочетании индивидуально-психологических особенностей человека и его опыта отношений, имеющихся коммуникативных знаниях, умениях и навыках, определенных социализацией, личностных, профессиональных ценностей, мотивации и направленности личности.

7. Доверие к процессу жизни. Наряду с рациональными установками, ориентацией на успех, сознательным планированием своей жизни необходимо то душевное качество, которое в психоанализе определялось как «базовое доверие» (Э. Эриксон). По иному это можно было бы обозначить, как умение следовать естественному течению процесса жизни, где бы и в чем бы он не проявлялся.

Соответственно, для субъективно благополучного человека одной из базовых задач является сохранение и улучшение качества психологического здоровья. В этом направлении необходима сознательная, целенаправленная работа самого человека по восстановлению и развитию жизненных ресурсов, по принятию на себя ответственности за собственное здоровье, когда здоровый образ жизни становится потребностью.

При условии выделения компонентов психологического здоровья возникает возможность определения задач развития и коррекции в ходе активности и жизнедеятельности человека:

- обучение положительному самоотношению и принятию других;

- обучение рефлексивным умениям;

- формирование потребности в саморазвитии.

Данные задачи соотносятся с функциями и компонентами психологического здоровья и субъективного благополучия. Однако, можно отметить, что основной акцент делается на обучении, на предоставлении человеку возможности изменений, как возможности самостоятельно принять решение о вариативности своей жизни.

О.В. Хухлаева для описания психологического здоровья использует базовое понятие «гармония», или «баланс». Это гармония между различными составляющими самого человека: эмоциональными и интеллекту- альными, телесными и психическими, гармония между человеком и окружающими людьми и пр. При этом гармония рассматривается не как статическое состояние, а как процесс. Соответственно О.В. Хухлаева говорит о том, что психологическое здоровье представляет собой динамическую совокупность психических свойств человека, обеспечивающих гармонию между потребностями индивида и общества, являющихся предпосылкой ориентации личности на выполнение своей жизненной задачи. Жизненную задачу при этом автор рассматривает рассматривать как то, что необходимо сделать для окружающих именно конкретному человеку с его способностями и возможностями. Выполняя жизненную задачу, человек чувствует себя счастливым, в противном случае - глубоко несчастным [10].

Если согласиться с тем, что «ключевым» словом для описания психологического здоровья является слово «гармония», то в качестве центральной характеристики психологически здорового человека О.В. Хухлаева называет саморегулируемость, т.е. возможность адекватного приспособления как к благоприятным, так и к неблагоприятным условиям, воздействиям. Акцент делается на возможных трудностях адаптации именно к благоприятной ситуации. К ним-то человек всегда готов и они не потребуют особого напряжения. Если же говорить об адаптации к трудным ситуациям, то необходимо уметь не только противостоять им, но и использовать их для самоизменения, для роста и развития. Таким образом, О.В. Хухлаева делает вывод о том, что основная функция психологического здоровья - это поддержание активного динамического баланса между человеком и окружающей средой в ситуациях, требующих мобилизации ресурсов личности.

Анализ литературы и исследования О.В. Хухлаевой позволяют утверждать, что психологическое здоровье можно описать как систему, включающую аксиологический, инструментальный и потребностно-мотивационный компоненты [10].

Для организации развития человека и его самоактуализации в целях выхода на субъективное благополучие и поддержание психологического здоровья в исследованиях рассматриваются факторы риска нарушения психологического здоровья и оптимальные условия его становления [7].

Итак, качество психологического здоровья рассматривается как собственная жизнеспособность индивида, обеспеченная полноценным развитием и функционированием психического аппарата. Гармония душевных сил (разум, чувства, желания, воля и т.п.), необходимая для нормальной, самостоятельной жизнедеятельности, является предпосылкой здоровья психологического. Состояние психологического здоровья характеризует ин- 
дивида как субъекта жизнедеятельности. В связи с этим основу психологического здоровья составляет нормальное развитие субъективной реальности в онтогенезе.

Фактически все эти требования выходят в плоскость понимания и сохранения субъективного и психологического благополучия личности. Сохраняя психологическое здоровье личности, мы акцентируем категории благополучия: категорию «образ» как осознанный стиль жизни или образ желаемых целей; категорию «мотив» как побуждение к достижению индивидуально значимых целей или реализации желаемого образа жизни; переживание как чувства, которые «уведомляют» его об отношениях со средой, как чувства, которые испытывает индивид, сопоставляя свои усилия, действия к достижению желаемой цели или образа жизни, с тем, что он достиг в реальности или с тем, чего смогли достичь другие; категорию «эмоции» как эмоциональная оценка себя, своих достижений, степени удовлетворенности собой и своей жизнью.

\section{ЛИТЕРАТУРА}

1. Батурин Н.А., Башкатов С.А., Гафарова Н.В. Теоретическая модель личностного благополучия // Вестник ЮУрГУ. «Серия: Психология». - 2013. - № 4. - Т.6. - C. $4-14$.

2. Белоус 0.В. Факторы и условия поддержания психологического здоровья учителя // Вестник Пятигорского государственного лингвистического университета. Спецвыпуск. - $2008-$ с.103-106

3. Бенко Е.В. Обзор зарубежных публикаций, посвященных исследованию благополучия // Вестник ЮУрГУ. «Серия: Психология». - 2015. - № 2 - С. 5 - 13

4. Васильева 0.С., Пилатов Ф.Р. Психология здоровья человека: эталоны, представления, установки: Учеб.пособие для студентов высших учеб. заведений. - М.: Академия, 2001. - 352 с.

5. Воронина А.В. Проблема психологического здоровья и благополучия человека: обзор концепций и опыт структурно-уровневого анализа // Сибирский психологический журнал. - 2005. -№ 3. -С. 142- 145

6. Психология здоровья / под ред. Г.С. Никифорова. -СПб.: Питер, 2006. -607 с.

7. Психологическое здоровье детей и подростков в контексте психологической службы / под ред. И. В. Дубровиной. - Екатеринбург: Деловая книга, 2000. $-176 c$.

8. Савельева 0.С. Субъективное благополучие как проблема социальной психологии личности. - [Электронный ресурс]. - [Режим доступа]: http//www. elibrary.ru/

9. Соколова М.В. Шкала субъективного благополучия. - Ярославль, 1996

10. Хухлаева 0.В. Основы психологического консультирования и психологической коррекции. - М.: Академия, 2011. - 208 с.

11. Шамионов Р.М. Психология субъективного благополучия // Мир психологии. - №2. - 2002. - с. 143-148

12. Шевеленкова Т.Д., Фесенко П.П. Психологическое благополучие личности (обзор основных концепций и методика исследования) // Психологическая диагностика. - 2005. - № 3. - С. 95-129

13. Ryff C.D. Psychological Well-Being //Encyclopedia of Gerontology. - 1996. -Vol. 2. -P. 365-369

(c Белоус Ольга Валерьевна (belous_a@inbox.ru). 